\title{
Distribution and population structure in the naked goby Gobiosoma bosc (Perciformes: Gobiidae) along a salinity gradient in two western Atlantic estuaries
}

\author{
Christopher S Moore ${ }^{\text {Corresp., }}{ }^{1}$, Matthew J Ruocchio ${ }^{2}$, April MH Blakeslee ${ }^{2}$ \\ 1 Biology Department, East Carolina University, Greenville, NC, United States \\ 2 Biology Department, East Carolina University, Greenville, North Carolina, United States \\ Corresponding Author: Christopher S Moore \\ Email address: moorech16@students.ecu.edu
}

Many species of fish produce larvae that undergo a prolonged dispersal phase. However, evidence from a number of recent studies on demersal fishes suggests that the dispersal of propagules may not be strongly correlated with gene flow. Instead, other factors like larval behavior and the availability of preferred settlement habitat may be more important to maintaining population structure. We used an ecologically-important benthic fish species, Gobiosoma bosc (naked goby), to investigate local and regional scale population structure and gene flow along a salinity gradient ( $~ 3$ ppt to $\sim 18 \mathrm{ppt}$ ) in two North Carolina estuaries. $G$. bosc is an abundant and geographically widespread species that requires complex but patchy microhabitat (e.g. oyster reefs, rubble, woody debris) for reproduction and refuge. We sequenced 155 fish from 10 sites, using a common barcoding gene (COI). We also included recent sequence data from Genbank to determine how North Carolina populations fit into the larger biogeographic understanding of this species. In North Carolina, we found a significant amount of gene flow within and between estuaries. Our analysis also showed high predicted genetic diversity based upon a large number of rare haplotypes found within many of our sampled populations. Moreover, we detected a number of new haplotypes in North Carolina that had not yet been observed in prior work. Sampling along a salinity gradient did not reveal any significant positive or negative correlations between salinity and genetic diversity, nor the proportion of singleton haplotypes, with the exception of a positive correlation between salinity standard deviation and genetic diversity. We also found evidence that an introduced European population of naked gobies may have originated from an Atlantic source population. Altogether, this system offers a compelling way to evaluate whether factors other than dispersal per se mediate recruitment in an estuarine-dependent species of fish with a larval dispersal phase. It also demonstrates the importance of exploring both smaller and larger scale population structure in marine organisms to better understand local and 
regional patterns of population connectivity and gene flow. 
1

2

3

4 Christopher S. Moore ${ }^{1}$, Matthew J. Ruocchio ${ }^{1}$, April M.H. Blakeslee ${ }^{1}$

6

7 Corresponding Author:

8 Christopher S. Moore ${ }^{1}$

9 S103 Howell Science Complex, East $10^{\text {th }}$ Street, Greenville, NC, 27858, United States

10 Email address: moorech16@students.ecu.edu

11

12

13

14

15

16

17

18

19

20

21

22

23

24

25

26

27

28

29

30

31

32

33

34

35

36

37

38

39

40

41
Gobiidae) along a salinity gradient in two western Atlantic estuaries

${ }^{1}$ Biology Department, East Carolina University, Greenville, North Carolina, United States

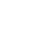

(1)

(7)

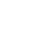

(1)

1

2

8




\section{Abstract}

Many species of fish produce larvae that undergo a prolonged dispersal phase. However, evidence from a number of recent studies on demersal fishes suggests that the dispersal of propagules may not be strongly correlated with gene flow. Instead, other factors like larval behavior and the availability of preferred settlement habitat may be more important to maintaining population structure. We used an ecologically-important benthic fish species, Gobiosoma bosc (naked goby), to investigate local and regional scale population structure and gene flow along a salinity gradient $(\sim 3 \mathrm{ppt}$ to $\sim 18 \mathrm{ppt})$ in two North Carolina estuaries. G. bosc is an abundant and geographically widespread species that requires complex but patchy microhabitat (e.g. oyster reefs, rubble, woody debris) for reproduction and refuge. We sequenced 155 fish from 10 sites, using a common barcoding gene (COI). We also included recent sequence data from Genbank to determine how North Carolina populations fit into the larger biogeographic understanding of this species. In North Carolina, we found a significant amount of gene flow within and between estuaries. Our analysis also showed high predicted genetic diversity based upon a large number of rare haplotypes found within many of our sampled populations. Moreover, we detected a number of new haplotypes in North Carolina that had not yet been observed in prior work. Sampling along a salinity gradient did not reveal any significant positive or negative correlations between salinity and genetic diversity, nor the proportion of singleton haplotypes, with the exception of a positive correlation between salinity standard deviation and genetic diversity. We also found evidence that an introduced European population of naked gobies may have originated from an Atlantic source population. Altogether, this system offers a compelling way to evaluate whether factors other than dispersal per se mediate recruitment in an estuarine-dependent species of fish with a larval dispersal phase. It also demonstrates the importance of exploring both smaller and larger scale population structure in marine organisms to better understand local and regional patterns of population connectivity and gene flow.

\section{Introduction}

The Gobiidae is the largest family of marine fishes, with nearly 2000 species described worldwide, an estimated 320 of which are found in the Americas (Van Tassell 2011; pers. comm). Cryptic by nature, gobies are small ( $<70 \mathrm{~mm}$ standard length) benthic fishes that are sedentary as adults. Most species inhabit tropical and sub-tropical regions (Thacker 2011); however, some taxa, including members of the genus Gobiosoma, are also found in temperate latitudes in the western Atlantic. Although common across a broad range of estuarine habitats and salinity gradients, the Gobiosoma remain relatively understudied (Carle \& Hastings 1982; Van Tassell 2011).

One member of this genus, the naked goby Gobiosoma bosc (Lacépède, 1800), is a geographically widespread species - ranging from Connecticut to Campeche, Mexico - and the most commonly encountered gobioid fish in estuaries of the southeastern United States (Dawson 1969; Ross \& Rhode 2004). This small goby ( $<60 \mathrm{~mm} \mathrm{SL}$ ) is estuarine-dependent (Able \& Fahay 1988, 2010) and prefers structured habitat (e.g. oyster reefs, woody debris). G. bosc is most abundant in waters of low-to-moderate salinity (Dahlberg \& Conyers 1972), though it may also occupy sub-tidal mud flats or the shallow margins of marsh creeks (Miller \& Guillory 1980; Peterson \& Ross 1991; Hendon et al. 2000). Naked gobies function as an important trophic link 
between benthic and pelagic communities (Markle \& Grant 1970; Breitburg et al. 1995; Breitburg 1999).

Early studies characterizing the life history and distribution of $G$. bosc focused on its reproductive biology and the distribution and abundance of larvae and adults as a function of salinity (Massmann et al. 1963; Dawson 1966; Dahlberg \& Conyers 1972; Crabtree \& Middaugh 1982; Shenker et al. 1983; Conn 1989). Planktonic G. bosc larvae settle out and become part of the benthos at an approximate total length of 7-12 mm (Borges et al. 2011). Prior to settlement, larvae aggregate in low flow areas on the downcurrent side of oyster reefs (Breitburg et al. 1995), which serve as the preferred habitat for juveniles and adults and are also integral to goby refuge and reproduction (Nelson 1928; Massmann et al. 1963; Dahlberg \& Conyers 1972; Shenker et al. 1983; Lederhouse 2009). In particular, adhesive egg masses are attached to the underside of oyster shells (e.g. Dahlberg \& Conyers 1972; Crabtree \& Middaugh 1982), and eggs hatch after approximately 1-2 weeks (Nero 1976). Early-stage larvae are subject to passive dispersal processes, while larvae in more advanced stages of development are capable of positive rheotaxis and have been observed to aggregate around oyster reefs, or other structured habitat like rubble or artificial structures, prior to settlement (Breitburg et al. 1989, 1991, 1995).

Due to its dependence on structured habitat for refuge and reproduction, spatially-mediated patterns of G. bosc larval settlement may determine local population densities throughout estuarine habitats (Breitburg et al. 1995). Oyster reefs in particular form a complex spatial mosaic in estuaries, along with mudflats, submerged aquatic vegetation (SAV), and emergent vegetation (e.g. Bell et al. 1991; Skilleter \& Loneragan 2003; Gain et al. 2017), and this mosaic will in turn strongly influence goby abundance and distributional patterns. Further, larval G. bosc have been reported to migrate towards lower salinity regions in estuaries (e.g. Shenker et al. 1983); however, the home range of adult naked gobies and their ability to disperse downstream remain unknown (Ross \& Rhode 2004). In sedentary fishes like G. bosc, it is assumed that dispersal promotes connectivity between populations that are otherwise isolated within such habitat mosaics (Leis \& McCormick 2002; Shanks 2009). In other words, long-distance dispersal of larvae over many kilometers would be expected to result in a relatively uniform population structure, especially at smaller spatial scales (Palumbi 1994; Shulman \& Bermingham 1995; Mora and Sale 2002; Palumbi \& Warner 2003). However, evidence from demersal tropical and Antarctic fishes suggests that self-recruitment and local adaptation can persist despite widespread gene flow (Ohman et al. 1998; Robertson 2001; Taylor \& Hellberg 2003; Moody et al. 2015). This has led many to conclude that larval behavior and the availability of settlement habitat are more important predictors of population structure than dispersal alone (Shanks 2009; Riginos et al. 2011; Kohn \& Clements 2011).

To date, few studies have attempted to quantify population connectivity in temperate fishes (e.g. Kohn \& Clements 2011) like G. bosc. However, a recent study on the population genetics of naked gobies (Mila et al. 2017) has provided some understanding of the large-scale phylogeographic differences throughout much of the species' range. This investigation found that G. bosc is strongly structured based on geography, particularly between Gulf vs Atlantic populations, but within those major regions, gobies are further subdivided into subclades based upon geography (e.g., East and West of the Apalachicola River along the Florida panhandle), due to biogeographic breaks that inhibit gene flow. The Mila et al. (2007) study is therefore 
instrumental in understanding the broader phylogeography of G. bosc in North America. To date, however, there have been no studies investigating genetic diversity at smaller scales (i.e. at the estuary level). This is particularly relevant given the importance of suitable habitat in structuring populations of naked gobies, which are otherwise isolated from one another as adults within a broader habitat matrix.

In our study, we collected G. bosc along a salinity gradient from two North Carolina estuaries in order to quantify population connectivity within and between estuaries, and also to better understand the role of habitat and salinity in mediating gene flow and local adaptation. While naked gobies have a broad salinity tolerance $(<1.0 \mathrm{ppt}-32 \mathrm{ppt}$.), they have been noted as most abundant in salinities below 24 ppt (Massman et al. 1963; Shenker et al. 1983), and in North Carolina, we have observed adults to be most abundant in low-to-mid mesohaline habitats (5.0 $\mathrm{ppt}-16.0 \mathrm{ppt}$ ) (personal observations). We therefore hypothesized that populations in oligohaline $(<5.0 \mathrm{ppt})$ and polyhaline $(>24.0 \mathrm{ppt})$ salinities may be more subject to processes that lower genetic diversity, like drift.

To quantify population structure in these estuaries, we used the common mitochondrial barcoding gene Cytochrome Oxidase I, which has been used as a tool for population genetics studies across multiple diverse taxa over the past 20+ years (COI 2014; Barcode 2018), and has proven effective at sequencing the genetic diversity of marine fishes (e.g. Ward et al. 2005). Furthermore, the use of this marker allowed us to explore our data in combination with other recent population genetics datasets for this species, like the Mila et al. (2017) study, and an additional goby phylogenetics study encompassing multiple goby species (e.g. Van Tassell et al. 2015). It is also noteworthy that although the comprehensive Mila et al. (2017) study sampled $G$. bosc throughout most of its range, it did not include samples from North Carolina, a state which features the second largest estuarine system in the USA (APNEP 2018). Our work provides a greater understanding of the importance of large estuaries in the life history G. boscparticularly related to patterns of dispersal and connectivity among isolated populations of these and similar fishes. This work could therefore have important implications for the management of marine protected areas (MPAs), or other conserved habitats that are spatially segregated but connected by gene flow.

\section{Materials and Methods}

\section{Study location}

Gobiosoma bosc fish were sampled along a salient gradient spanning the Pamlico and Neuse River estuaries in the North Carolina coastal plain (Fig. 1; Table 1). Both the Pamlico and Neuse are shallow (average depth 1-3 m), microtidal $(<1 \mathrm{ft}$. tidal range), oligohaline-mesohaline $(0.5$ $\%$ to $18 \%$ ) estuaries that combine to form Pamlico Sound: the largest lagoonal estuary in the United States (Bales \& Nelson 1988). The Pamlico River estuary is a continuation of the freshwater Tar River, and it flows approximately $65 \mathrm{~km}$ from the town of Washington, NC to Pamlico Sound. The Neuse River estuary begins in New Bern, NC, and empties into Pamlico Sound. For comparison to samples collected from sites along the Pamlico and Neuse rivers, fish were also collected from Hoop Pole Creek Nature Preserve (HPC), which is located along Bogue Sound in Atlantic Beach, NC (Fig. 1) and is part of the Pamlico Sound. 
180

181

182

183

184

185

186

187

188

189

190

191

192

193

194

195

196

197

198

199

200

201

202

203

204

205

206

207

208

209

210

211

212

213

214

215

216

217

218

219

220

221

222

223

224

\section{Specimen collection}

From February to July 2017, naked gobies were sampled $(n=155)$ from nine locations along the Pamlico and Neuse River estuaries, in addition to the site at Hoop Pole Creek (Fig 1; Table 1) (North Carolina Division of Marine Fisheries Scientific or Educational Permit Number 706671). Fish were collected using passive collecting devices: small plastic milk crates $(19.05 \mathrm{x} 22.10 \mathrm{x}$ $15.75 \mathrm{~cm}$ ) filled with approximately $1.7 \mathrm{~kg}$ of autoclaved oyster shell. This technique is modeled on the successful methodology employed by the Smithsonian Environmental Research Center (SERC) for the past twenty years, e.g. Roche \& Torchin (2007), and within our lab for the past 5 years. Although G. bosc and other organisms can freely move inside and outside the crates, they are attracted to the complex three-dimensional habitat that the shell provides. This is analogous to the collecting strategy used by D'Aguillo et al. (2014), who employed habitat traps (i.e. "shellrubble trays": $0.8 \mathrm{~m}^{2}$ plastic trays covered with $0.6 \mathrm{~cm}$ mesh netting and filled with oyster shell) to sample specifically for naked gobies.

Two replicate crates were deployed at each sample location, making for a total of ten collecting units on the Neuse River and eight on the Pamlico River. Crates were zip-tied to $0.75 \mathrm{~m}$ wooden stakes secured in the nearshore subtidal zone, or deployed from fixed or floating docks using rope. Crates on both rivers were checked every 6-8 weeks, and the contents sorted using a large sieve $(55.9 \times 55.9 \times 12.7 \mathrm{~cm})$ with $2 \mathrm{~mm}$ mesh. A maximum of ten naked gobies were collected from each sample site during each sampling event. In order to minimize selection bias, fish from both crates were pooled together, and ten individuals were randomly selected from a grid divided into four quadrants. Only sexually mature adults were used in this study. Therefore, all fish less than $20 \mathrm{~mm}$ SL (i.e. Dahlberg \& Conyers 1973) were released at a minimum distance of $50 \mathrm{~m}$ from the collecting location. Fish were then live-transported to East Carolina University (ECU) and housed in aerated plastic aquaria $(36.83 \times 22.35 \times 24.38 \mathrm{~cm})$ at a salinity approximating that of the collecting location. All collection and housing protocols were approved by ECU IACUC: AUP \#D346. Because our sample sites were located along a salinity gradient, salinity data were collected at each site using a handheld YSI (YSI Inc., Yellow Springs, OH). These point measurements were averaged across all sampling events $(n=4)$ to provide an average salinity value for each site that could be regressed against genetic (haplotype) diversity at each sample location.

\section{DNA Sequencing and Analysis}

Naked gobies were dissected as part of an unrelated study assessing parasite diversity in these fish, and thus sampled fish were not released following capture. Once dissected, white muscle tissue was saved from each individual and immediately preserved at $-20{ }^{\circ} \mathrm{C}$ for later DNA extraction. Genomic DNA was isolated from tissue samples using proteinase K/SDS digestion, chloroform extraction, and ethanol precipitation (Kocher et al. 1989). Cytochrome Oxidase I (COI) PCR primers were designed based on sequence data from Van Tassell et al. (2015). These newly designed primers were: GOBY COI F: GCACCGCTTTAAGCCTTTTA and GOBY COI R: TGGTGTTGAGGTTTCGGTCT. The PCR profile is as follows: $95{ }^{\circ} \mathrm{C}$ for 2-min; 30 cycles of $95{ }^{\circ} \mathrm{C}$ for $30 \mathrm{~s}, 55^{\circ} \mathrm{C}$ for $30 \mathrm{~s}$, and $72{ }^{\circ} \mathrm{C}$ for $60 \mathrm{~s}$; and $72{ }^{\circ} \mathrm{C}$ for 5 -min (Blakeslee et al. 2017). 
225 PCR amplicons were purified using ExoSAP-IT ${ }^{\text {TM }}$ (ThermoFisher Scientific). Samples were then sent for Sanger sequencing to Macrogen USA (Rockville, MD).

Sequences were manually cleaned, inspected for ambiguities, and aligned without gaps to a reference sequence in Genbank (accession \#: KM077829.1) using Geneious10.1.2 (Biomatters Ltd., Auckland, New Zealand). This resulted in a 530 base-pair fragment of the COI gene across all samples ( $\mathrm{n}=155$ individuals from North Carolina; accession numbers: XXXXXXXXXXXXXXXX). In addition, 66 additional G. bosc sequences were located on Genbank following a BLAST search (https://blast.ncbi.nlm.nih.gov/Blast.cgi) with 100\% coverage of the 530 basepair COI fragment. These included 57 sequences (Popset: 1229627432; accession \#s: MF168978-MF169034) from a recent and comprehensive population genetics investigation of $G$. bosc in several North American populations, including New York, Virginia, South Carolina, Atlantic Florida, Gulf Florida, Louisiana, Mississippi, and Texas (Mila et al. 2017). An additional 9 sequences came from a study by Van Tassell et al. (2015): 5 of these were from a non-native population (Germany) and 4 were from the USA (Florida and the Gulf of Mexico) (accession \#s: KT278516, KT278523, KT278535, KT278549, KT278552, KM077826, KM077829, KT278549, and KM077828).

Our new sequences were combined with the sequences from Genbank and aligned using Geneious 10.1.2. Sequences were then collapsed into haplotypes using TCS1.21 (Clement et al. 2002) (Table S1). The Mila et al. (2017) popset (\#1229627432) from Genbank included an incidence-based understanding of the haplotypes found across the Atlantic and Gulf of Mexico. In other words, this popset contained no information on haplotype frequencies per population. On the other hand, our North Carolina dataset included frequency data that were explored between and among North Carolina populations and estuaries. As a result, two separate analyses were performed: (1) an investigation for North Carolina populations only, and (2) a geographic, incidence-based investigation of all haplotypes (including our new North Carolina ones) detected across the geographic range. This latter analysis determined how naked gobies in North Carolina fit into the larger biogeographic picture.

\section{Genetic Analyses}

For our first analysis focused on North Carolina, we estimated the hierarchical analysis of molecular variance (AMOVA) using ARLEQUIN311 (Excoffier et al. 2005). Resulting fixation indices helped pinpoint whether there was divergence among populations and between the two major estuaries in our study. Pairwise $\phi$ STs were calculated using ARLEQUIN (Table S2) and visualized in a non-metric multidimensional scaling analysis (using PRIMER 7.0.13 (Primer-e, Quest Research Limited, Auckland, New Zealand) to look for spatial patterns among populations. We used PopArt (http://popart.otago.ac.nz/index.shtml) to graphically create haplotype networks.

We also used ARLEQUIN to obtain genetic diversity values for each population to investigate whether there was any effect of salinity on haplotype diversity in the North Carolina populations. For this salinity analysis, we included sites that were sampled from the two rivers ( $\mathrm{n}=9$ sites: 4 in the Pamlico River and 5 in the Neuse River). We used JMP Pro 13 (SAS Institute Inc., Cary, NC) to regress salinity with a) genetic diversity and b) the proportion of singleton haplotypes 
271 (calculated from the haplotype analysis described above). This latter approach was used to 272 determine whether there was any influence of salinity on the proportion of rare haplotypes in a 273 population. Additionally, given the variability in salinity within these systems, we also explored

274

275

276

277

278

279

280

281

282

283

284

285

286

287

288

289

290

291

292

293

294

295

296

297

298

299

300

301

302

303

304

305

306

307

308

309

310

311

312

313

314

315

316 whether there was any relationship between the standard deviation of salinity and genetic diversity.

In addition, Primer 7.0.13 was used to construct rarefaction and extrapolation curves of haplotype diversity in order to determine the accumulation of haplotypes with sample size, the expected haplotype richness in each estuary, and the number of samples that would produce an asymptote in haplotype richness (extrapolation). Nonparametric estimators have been found useful in a number of studies for predicting the eventual asymptote in richness of a particular population (Gotelli and Colwell 2001) and do so by including the effects of rare (or singleton) species/haplotypes (Witman et al. 2004, Chao 2005; Blakeslee et al. 2008, 2012). A clearly asymptoting accumulation curve indicates complete capture of the total richness in a population (Gotelli and Colwell 2001), thus estimator curves and accumulation curves that converge on the same asymptote can be very useful in determining whether there is adequate sampling in a population or region, or whether more sampling would reveal additional species/haplotypes (Walther and Morand 1998; Blakeslee et al. 2008).

For our second analysis focused on goby biogeography, we performed an AMOVA to explore differences at the subregional level and also at the larger regional level, specifically between the Atlantic and Gulf of Mexico regions. We again used PopArt to graphically create haplotype networks, using incidence-based data from Mila et al. (2017), Van Tassell et al. (2015), and our new North Carolina populations. In this analysis, we also included five sequences from a nonnative population in Germany (Van Tassell et al. 2015) to identify if a source for the non-native population could be revealed within the overall dataset.

\section{Results}

\section{North Carolina Estuaries}

In our North Carolina dataset (Fig. 1; Table 1), we uncovered a total of 30 previously undescribed haplotypes. Among these haplotypes, 74\% of our 155 individuals (from four sites in the Pamlico estuary and five sites in the Neuse estuary, and also a site from Bogue Sound) were found to share one dominant haplotype (HAP5). The dominance of this haplotype and the connections among it and the other haplotypes in the estuaries can be observed in the haplotype network of North Carolina populations (Fig. 2). For our two major estuaries (Pamlico, n=88, and Neuse, $n=59)$, this haplotype (HAP5) was slightly more frequent in the Pamlico (78\%) versus the Neuse (68\%). At the haplotype level, most haplotypes were singleton occurrences: in the Pamlico, $60 \%$ of the haplotypes were singletons, and in the Neuse, $74 \%$ were singletons. When comparing between the Neuse and Pamlico sites, just 4 haplotypes (14\%) were shared between the estuaries; thus at the haplotype level, there was much less overlap between them. However, at the individual level, $86 \%$ of the Neuse individuals shared haplotypes with the Pamlico, and $76 \%$ of the Pamlico individuals shared haplotypes with the Neuse. This was supported by nonsignificant differentiation in the AMOVA comparing these two estuaries ( $\mathrm{FCT}=-0.00149$; $\mathrm{p}=0.44282$ ). It is important to note, however, that most of the sharing between estuaries and 
among populations occurred with the dominant haplotype, HAP5. In addition to the dominant haplotype (HAP5), the second most frequent haplotype (HAP27) was also comprised of individuals from both estuaries, as well as Bogue Sound.

At the population level (Fig. 3), the following sites were significantly (or nearly significantly) different from one another in pairwise $\phi_{\mathrm{ST}}$ analyses after accounting for multiple pairwise comparisons (Bonferroni correction, $\mathrm{p}=0.005)$ : MLC and CQC $(\mathrm{p}<0.001)$; MLC and HPC $(p=0.009)$; and NCL and HPC ( $p=0.009)$. In addition, Table 1 lists the ratio of observed vs. expected haplotypes vis-à-vis the number of fish sampled at each site. GSC and CQC were found to have the greatest genetic diversity, with the number of expected haplotypes predicted to be roughly three times greater than what was actually observed. Both of these sites are classified as low in salinity (Table 1). Fish from all other sites (MLC, NCL, WRC, FSL, MTP, POC, CDI, HPC) occupied the full range of salinity (low-medium-high) and demonstrated between one and two times the expected number of haplotypes compared to the number sampled. At the estuary level (Fig. 4 A-B), 8 times more haplotypes were predicted for the Neuse $(n=160)$ in the extrapolation curve than were actually detected $(n=20)$, and for the Pamlico $\sim 5$ times more haplotypes were predicted $(n=80)$ than were detected $(n=15)$. Comparing between the estuaries, the Neuse was $\sim 2.5$ times greater in predicted diversity than the Pamlico. Such diversity differences between the estuaries were also supported by a Shannon diversity test, finding $\mathrm{H}^{\prime}=$ 1.55 for the Neuse and $H^{\prime}=1.06$ for the Pamlico.

In explorations of salinity and genetic diversity/proportion of singleton haplotypes, we found no significant correlations for the following regressions: genetic diversity and salinity $\left(\mathrm{R}^{2}=0.004\right.$; $\mathrm{p}=0.873$; Fig. $5 \mathrm{~A})$, the proportion of singleton haplotypes and average salinity $\left(\mathrm{R}^{2}=0.070\right.$; $\mathrm{p}=0.490$; Fig. $5 \mathrm{~B}$ ), and the proportion of singleton haplotypes and salinity standard deviation $\left(\mathrm{R}^{2}=0.187 ; \mathrm{p}=0.245\right.$; Fig. 5D). At the population level, there was seemingly little influence of salinity and genetic relatedness. For example, two spatially similar sites (in terms of pairwise $\phi S T s), C D I$ and NCL, had salinities that were separated on average by $6 \mathrm{ppt}$, and these sites were also found in different estuaries. However, there was a significant positive correlation between the standard deviation of salinity and genetic diversity $\left(\mathrm{R}^{2}=0.500 ; \mathrm{p}=0.034 ;\right.$ Fig. $\left.5 \mathrm{C}\right)$. No correlations were found when estuaries were analyzed separately, nor did non-linear regressions improve fit and significance in any of these analyses, except in the case of the second polynomial for the proportion of singleton haplotypes and salinity standard deviation $\left(\mathrm{R}^{2}=0.792 ; \mathrm{p}=0.009\right)$ (Table S3).

\section{Biogeographic Comparison}

In our second analysis (Fig. 6), we combined G. bosc sequences from the public sequence repository, Genbank, with our own North Carolina estuary samples. For this analysis, we explored regional differentiation across North America, including the mid-Atlantic (New York and Virginia), North Carolina (Neuse, Pamlico, Bogue), South Carolina, Atlantic Florida, Florida Gulf, Florida panhandle, and other Gulf states (Louisiana, Mississippi, and Texas). In addition, we included 5 sequences found in a non-native population in Germany (Weser estuary). Except for North Carolina, these samples came from two studies: Mila et al. 2017 and Van Tassell et al. 2015. Among all these samples, a total of 88 haplotypes were found. These haplotypes were significantly regionally differentiated $(\mathrm{p}<0.001)$, with North Carolina falling in with the 
southeast and mid-Atlantic samples. When comparing Atlantic versus Gulf of Mexico sites, there was significant differentiation between the two major regions $(p<0.001)$ (Fig. 6).

\section{Introduced German Population}

At this point in time, any comparison with the non-native population (Weser estuary, Germany) must be taken with caution, as there are just a few $(n=5)$ representative sequences from this region (Van Tassell et al. 2015). However, in the haplotype analysis (see red coloration in Fig. 6) all five of those sequences aligned within the Atlantic network, with two individuals sharing haplotypes with Atlantic Florida and the mid-Atlantic. There was no evidence for a connection to the Gulf of Mexico. Additional data from the non-native region could help pinpoint a more specific origin for this non-native population.

\section{Discussion}

G. bosc is an important member of estuarine communities, but much remains unknown about the dispersal potential of this species, especially at smaller scales, and how it may influence gene flow among populations within a habitat mosaic, or among estuaries. Recent genetic work has focused on broader questions of phylogenetic relationships among the genus Gobiosoma (Van Tassell et al. 2015) and large-scale differentiation in widespread populations of G. bosc (Mila et al. 2017). Our study is the first to focus on smaller-scale patterns of connectivity and gene flow in naked gobies using a major estuarine system as our focal region. Our study also contributes previously undocumented sequence data from North Carolina populations of G. bosc, which will help in further resolving questions related to gene flow in this species at both the local and biogeographic scales. In addition, we incorporated a salinity gradient into our study design, as previous research has suggested that salinity is an important abiotic factor in the life history of this fish. To the contrary, we found that salinity alone was not a major predictor of genetic diversity in this species (with the exception of salinity variability), even though reports in the literature find naked gobies to be most abundant in moderate salinity habitats. In the sections that follow, we expand upon these findings and discuss their implications.

\section{Genetic Diversity, Gene Flow, and Connectivity}

Spatially-structured populations are linked by the dispersal of individual organisms (Cote et al. 2010). Dispersal itself is a fundamental life-history trait (Schludermann et al. 2012), and connectivity between distant groups is a major driver of population dynamics (Bignami et al. 2013). Moreover, the availability of stable epibenthic substrate is crucial for maintaining populations of estuarine fishes like G. bosc as well as other organisms (Allen \& Barker 1990; Shima \& Swearer 2009; Gain et al. 2017). In North Carolina, gene flow was broadly distributed across G. bosc populations between the Pamlico and Neuse estuaries (Fig. 2), and genetic diversity was quite high. The latter is especially reflected in the proportion of singleton haplotypes within populations (Table 1), which reached as high as $75 \%$ in one Neuse population and was close to $50 \%$ when averaged across all 9 populations. Such a preponderance of singleton haplotypes suggests a significant amount of genetic diversity remains unaccounted for in this system. In fact, rarefaction and extrapolation curves (Fig. 4 A-B) suggest upwards of 1000s of 
408 individuals would need to be sampled to produce an asymptote; in turn, greater sampling would produce significantly more haplotypes in each estuary than were initially detected.

In addition to demonstrating high diversity and a large number of singleton haplotypes (just a couple mutation steps away from the dominant haplotype), the star-like pattern of the haplotype network is also a well-known signature of populations that have undergone recent expansion (e.g., Mila et al. 2000; Frattini \& Vannini 2002). For example, star-like patterns (together with other molecular analyses; e.g., Fu's $F_{\text {s }}$ and Tajima's D) detected in the haplotype network of the protist Plasmodium falcipram (which infects African mosquitos) demonstrated clear population expansions for the parasite (Joy et al. 2003). In a marine example, star-like patterns were observed in haplotype networks of the spiny lobster (Palinurus gilchristi) in South Africa, suggesting a recent bottleneck and/or population expansion (Tolley et al. 2005). Specific to $G$. bosc, there is little understanding of this fish's ecological and demographic history in this region, and as a result, any explanations of the mechanisms responsible for population expansion are inherently speculative. However, as winds are the main driver of currents and water level in the Pamlico and Neuse estuaries (Luettich et al. 2002; Whipple et al. 2006), larval G. bosc would be highly susceptible to wind-driven dispersal while remaining planktonic in the water column. Given the severe storms that frequent the region (and also coincide with seasonal spawning activity of $G$. bosc), our evidence for a possible population expansion could be a response to one or more of the 35 tropical cyclones to affect coastal North Carolina over the past two decades (Paerl et al. 2018), or perhaps could be due to recent temperature and climactic changes in the region (Harley et al. 2006). A greater understanding of the interaction between the biology of this species and the multiple abiotic factors shaping its distribution, reproduction, and gene flow in the past and present is therefore needed.

Naked gobies also demonstrate extensive gene flow between and among populations in both estuaries, but especially within the Pamlico River. For example, in the MDS plot of pairwise $\phi S T$ s (Fig. 3), Pamlico sites are closer together spatially than Neuse sites. The location of our sample sites along each river, as well as the topography of the two rivers themselves, could be influential in differentially affecting gene flow in these rives. Most of our sites were located on creeks that were tributary to the main stem of either river. Although these sites were all positioned within $1 \mathrm{~km}$ of the river, some creeks would be subject to more flushing than others, while more hydrodynamically-isolated areas would favor greater larval retention. In addition, the orientation of the Pamlico itself is straighter (Fig. 1) and thus may be more favorable to winddriven dispersal relative to the Neuse, the latter demonstrating an orthogonal bend between the upper and lower parts of the estuary. In some areas of the Neuse estuary, this may possibly lend itself to greater larval retention, greater isolation, and potentially more locally adapted populations. Retention zones have been detected in numerous marine systems and are highly important to the genetic structure and diversity exhibited among populations of organisms connected by larval dispersal (Palumbi 1994; Pringle \& Wares 2007; Pringle et al. 2011). Larval dispersal is especially important in organisms that are much less mobile (or sessile) as adults (Sotka et al. 2004). While fish tend to be highly mobile during both larval and adult stages, fish species like G. bosc that are more associated with the benthos and have strict habitat requirements may be more influenced by retention zones that will influence gene flow and genetic structure within a region. In future studies, it would be important to map the availability 
453 of preferred settlement habitat in each river to determine how well it corresponds to the observed distribution of haplotype frequencies among our sample locations.

\section{The Role of Salinity and Habitat Preference}

Fish were collected along a salinity gradient averaging 3 to $14 \mathrm{ppt}$ (averaged across four time periods in 2017) (Table 1). Although G. bosc is a euryhaline species, salinity alone did not seem to affect the distribution of haplotype frequencies across our sample sites, even though the greatest abundance of larval naked gobies in plankton tows has been reported from mesohaline habitats (e.g. Dawson 1966; Shenker et al. 1983). In our study, adult naked gobies were most abundant in sites ranging from $4-12$ ppt. We therefore expected greater genetic diversity in fish collected from mesohaline sites because of their relative abundances. However, our results (Fig. 5) revealed few significant linear or non-linear trends with salinity (albeit our sampling only incorporated a single polyhaline site) with two exceptions: 1) we found a significant positive relationship between genetic diversity and salinity standard deviation (Fig. 5C), whereby sites with greater salinity variability possessed greater genetic variability; and 2) we found a significant positive relationship between the proportion of singleton haplotypes and salinity standard deviation (Table S3). Such an outcome could signify the influence of neutral processes like the effects of waves and currents as one moves upriver, or potentially more fine-scale genetic structure as a result of varying salinity (Beheregaray \& Sunnucks 2001). Alternatively, it may signal some kind of salinity adaptation occurring along salinity gradients in both estuaries. Though COI is generally treated as a neutral marker (i.e., it is widely used as a "barcoding" gene), this may not always be the case, particularly when linked to genes that are under greater selective pressures (Moritz \& Cicero 2004). Thus, differences in genetic variation along a salinity gradient may suggest an adaptive response (i.e., more variable salinity represents less stable conditions in a population); however, a genome-wide approach would be necessary to elucidate this potential influence on genetic variation in this system.

Further, previous studies have recognized the importance of habitat in structuring populations of G. bosc, but have also advocated for the major synergistic role that salinity plays for this fish species. Larval G. bosc approaching competence-to-settle are known to congregate near the downstream edges of oyster reefs, rubble, or artificial structures (Breitburg 1989, 1991, 1995). Adults are mostly sedentary and require hard substrate (e.g. oyster shell) for the attachment of egg masses, and it has been proposed that spawning is confined to the downriver portions of estuaries where this habitat is more common (Massamann et al. 1963; Shenker et al.1983). Shenker et al. (1983) reported that the abundance and size of larval G. bosc increased with time in the upriver portions of the Patuxent River estuary in Maryland, and they speculated that larvae were selectively using flood tides to move upriver. Upriver displacement of larvae offers a low salinity refuge from predation and is common in other estuarine-dependent species like weakfish Cynoscio regalis (Lankford \& Targett 1994) and red drum Sciaenops ocellatus (Stewart \& Scharf 2008). However, the synchronous spawning movement of adult G. bosc seems highly unlikely given that the species is cryptic and adapted to a benthic lifestyle. Adult G. bosc are opportunistic in their choice of spawning substrate, and in lieu of oyster shell will use rubble, woody debris, or other material like discarded cans (Nero 1976; Lehnert \& Allen 2002). Much like oyster shell, this habitat is often distributed haphazardly, and so population connectivity would depend on the quality, scale, and proximity of available habitat patches. G. bosc is adept 
at using such material, as evidenced by Miller et al. (2014), who extensively sampled a $155 \mathrm{~km}$ portion of the middle St. Johns River in Florida averaging 0.2 to $1.2 \mathrm{ppt}$. Based on the size and abundance of nearly 50,000 larval G. bosc, they unequivocally concluded that adults were spawning at all of their sample sites and that larvae were not being transported upriver. They also confirmed the presence of spawning adults and larvae in freshwater lakes and tributary streams of the St. Johns, which accords with our sampling of adult G. bosc in sites at the freshwater interface of the Pamlico River $(<0.1 \mathrm{ppt})$. Altogether, the evidence from prior studies and our own suggests that gene flow in this species is mediated by multiple biotic and abiotic factors principally among them the type of epibenthic substrate available as habitat, how the distribution of this habitat changes with salinity, and the location of suitable habitat relative to wind-forced circulation patterns.

\section{Biogeography of US Populations}

Biogeographic breaks leading to genetic differentiation have been detected in a number of marine organisms, and North Carolina in particular is positioned at one of the sharpest marine thermal boundaries in the world (Pietrafesa et al. 1985). As such, it functions as an important biogeographic break between temperate and sub-tropical regions. However, while we did not see a clear biogeographic break in Atlantic populations around North Carolina (as there were for the Gulf of Mexico; see discussion below), no shared haplotypes were detected between North Carolina and any other regions/subregions in the Atlantic - demonstrating that while there is a large amount of local gene flow within estuaries, there is much less gene flow at the regional level. Occasional stochastic weather events like tropical storms (AOML, NOAA 2017) may move individuals (particularly larvae) beyond these local boundaries, but these movements appear rare. For example, Ross and Rohde (2004) report just a single record of an adult G. bosc collected from an offshore scallop bed, and there are occasional reports of juveniles collected off Beaufort, N.C., located close to the Atlantic Ocean (Hildebrand \& Cable 1938).

In fact, Atlantic populations of G. bosc demonstrated less noticeable differentiation among geographically spaced locations than within the Gulf of Mexico (i.e., Atlantic locations were separated by fewer sequence changes than were Gulf locations). For example, in the Gulf, geographic differentiation was much more apparent with a considerable break at Apalachicola Bay, sub-dividing the Florida panhandle in two (Mila et al. 2017). In the Atlantic, it may be that the Gulf Stream is playing a role in the greater genetic connectivity (albeit still subregionally differentiated) that was detected among Atlantic populations compared to the Gulf of Mexico populations. The Gulf Stream is known to shape dispersal patterns in many marine fauna. For example, it is thought to be responsible for the presence of Caribbean mesopelagics in the northern Sargasso Sea (Jahn 1976), and some western Atlantic groups in the eastern Atlantic Azores archipelago (Avila et al. 2009). In addition, it also promotes gene flow among such widely distributed organisms as sea turtles (Blumenthal et al. 2009) and American and European eels (Kleckner \& McCleave 1982). These organisms all represent pelagic-spawning species whose larvae would be subject to long-distance transport, in contrast to G. bosc, which is an estuarine-resident organism. If the Gulf Stream does play a substantive role in gene flow among Atlantic populations of G. bosc, this might also help explain the importance of the tip of Florida representing a major biogeographic break. Off the southern tip of Florida in the Florida Straits, 
the Gulf Stream current flows east and is at its narrowest and strongest (Gula et al. 2015), which would likely reinforce divergence between Atlantic and Gulf populations at the regional scale.

\section{Status of a non-native German Population}

Very little is known about the non-native population of naked gobies in the Weser estuary, Germany. Thiel et al. (2012) reported that multiple individuals were collected in a stow net in 2009 by a commercial fishery vessel at a depth of between 11.0 and $14.3 \mathrm{~m}$ - unusually deep for this species. Without more information, it is unclear whether the population in Germany is more widespread or isolated to this particular estuary. Moreover, it is not possible at this point to determine a likely source location for this introduction, except that it appears likely to have come from an Atlantic source (i.e., in our network analysis, two Germany individuals were found to share haplotypes with an Atlantic Florida and a New York individual; Fig. 6). Given the distance between these two US Atlantic populations, this may suggest multiple introduction events from different source populations - a common occurrence among non-native species introduced via ballast water from shipping (e.g., Blakeslee et al. 2017). The Weser estuary is located near the border with the Netherlands and serves as an important commercial shipping hub, which led Thiel et al. (2012) to speculate that G. bosc was introduced via ballast water. An additional introduction has previously been reported from the Orinico Delta in Venezuela (Lasso-Alcala et al. 2005), which is also a major international shipping destination. In all probability, introduced populations of G. bosc are underreported owing to the species' small size and cryptic nature.

\section{Conclusions}

We stand to learn a great deal from studying common fish like G. bosc that, notwithstanding their abundance, remain relatively understudied in the literature. Only recently, for example, was a comprehensive analysis published on the feeding ecology of this species (e.g. D'Aguillo et al. 2014), which addressed basic questions like diet and daily patterns in foraging activity. In the future, we intend to continue to address the limited understanding of the basic biology of this species by resolving questions of adult dispersal - in particular by studying the movement patterns of adult G. bosc that reside in specific habitat patches. The distribution of adults also appears to be related to shoreline exposure, as areas with significant fetch tend to have fewer naked gobies and a higher relative abundance of other species like skilletfish Gobiesox strumosus and striped blennies Chasmodes bosquianus (pers. obs.). While adult G. bosc are relatively cryptic and do not appear to stray far from complex habitat, this remains an untested assumption that could potentially inform our understanding of population connectivity in this species at the estuary level. Further resolution of the genetic connectivity among populations should also include genome-level markers (i.e. RAD-Seq), as it can be difficult to develop a detailed understanding of the magnitude of gene flow at smaller scales using only frequencybased approaches (Waples 1998; Hellberg 2009). Even so, our study provides an initial understanding of the importance of investigating genetic diversity and population structure at local and regional scales.

\section{Literature Cited}


Able KW, Fahay MP. 1988. The First Year in the Life of Estuarine Fishes in the Middle Atlantic Bight. Rutgers University Press. New Brunswick, NJ. 342 pp.

Able KW, Fahay MP. 2010. Gobiosoma bosc (Lacepede): naked goby. In: Ecology of estuarine fishes: temperate waters of the western North Atlantic. Johns Hopkins university press, Baltimore.

Allen DM, Barker, DL. 1990. Interannual variations in larval fish recruitment to estuarine epibenthic habitats. Marine Ecology Progress Series 63: 113-125.

AOML - NOAA, 2017. Contributed by Landsea, C. Atlantic Oceanographic and Meterological Laboratory, Hurricane Research Division. http://www.aoml.noaa.gov/hrd/tcfaq/E11.html

APNEP. 2018. The Albemarle-Pamlico Estuary. Albemarle-Pamlico National Estuary Partnership. http://portal.ncdenr.org/web/apnep/our-estuaries

Avila SP, Marques da Silva C, Schiebel R, Cecca F, Back- eljau, T, de Frias Martins AM. 2009. How did they get here? The biogeography of the marine mollusks of the Azores. Bulletin de la Societe Geologique de France 180: 295-307.

Bales JD, Nelson TM. 1988. Bibliography of Hydrologic and Water Quality Investigations Conducted in or Near the Albemarle-Pamlico Sounds Region, North Carolina. Raleigh, NC: USGS; USGS Open-File Report 88-480.

Barcode of Life. 2018. Consortium for the Barcode of Life. http://www.barcodeoflife.org/content/about/what-dna-barcoding

Beheregaray LB, Sunnucks P. 2002. Fine-scale genetic structure, estuarine colonization and incipient speciation in the marine silverside fish. Odontesthes argentinensis. Molecular Ecology 10: 2849-2866.

Bell SS, McCoy ED, Mushinsky HR. 1991. Habitat structure: the physical arrangement of objects in space. Chapman and Hall, London.

Bignami S, Enochs IC, Manzello DP, Sponaugle, S, Cowen RK. 2013. Ocean acidification alters the otoliths of a pantropical fish species with implications for sensory function. Proc. Natl. Acad. Sci. U.S.A. 110: 7366-7370.

Blakeslee AMH, Byers JE, Lesser MP. 2008. Solving cryptogenic histories using host and parasite molecular genetics: the resolution of Littorina littorea's North American origin. Molecular Ecology 17: 3684 - 3696.

Blakeslee AMH, Altman I, Miller AW, Byers JE, Hamer CE, Ruiz GM. 2012. Parasites and invasions: a biogeographic examination of parasites and hosts in native and introduced ranges. Journal of Biogeography 39: 609-622.

Blakeslee AMH, Kamakukra Y, Onufrey J, Makino W, Urabe J, Park S, Keogh CL, Miller AW, Minton MS, Carlton JT, Miura O. (2017). Reconstructing the Invasion History of the Asian shorecrab Hemigrapsus sanguineus (De Haan 1835) in the Western Atlantic. Marine Biology 164: 47. doi:10.1007/s00227-017-3069-1.

Blumenthal JM, Abreu-Grobois FA, Austin TJ, Broderick AC, Bruford MW, Coyne MS Ebanks-Petrie G, Formia A, Meylan PA, Meylan AB, Godley BJ. 2009. Turtle groups or turtle soup: dispersal patterns of hawksbill turtles in the Caribbean. Molecular Ecology 18: 4841-4853.

Borges R, Faria C, Gil F, Goncalves EJ. 2011. Early development of gobies. In: The Biology of Gobies, Patzner RA, Van Tassell JL, Kovacic M, Kapoor BG, eds. CRC Press. Boca Raton, FL. 685 pp.

Breitburg DL. 1989. Demersal schooling prior to settlement by larvae of the naked goby. Environmental Biology of Fishes 26: 97-103. 
636

637

638

639

640

641

642

643

644

645

646

647

648

649

650

651

652

653

654

655

656

657

658

659

660

661

662

663

664

665

666

667

668

669

670

671

672

673

674

675

676

677

678

679
Breitburg DL. 1991. Settlement patterns and presettlement behavior of the naked goby, Gobiosoma bosc, a temperate oyster reef fish. Marine Biology. 109: 213-221.

Breitburg DL, Palmer MA, Loher T. 1995. Larval distributions and the spatial patterns of settlement of an oyster reef fish: responses to flow and structure. Marine Ecology Progress Series 125: 45-60.

Breitburg DL. 1999. Are three-dimensional structure and healthy oyster populations the keys to an ecologically interesting and important fish community? Pages 239-249. In: Oyster reef habitat restoration: a synopsis and synthesis of approaches, Luckenbach MW, Mann R, Wesson JA eds. Virginia Institute of Marine Science Press. Gloucester Point, VA. $336 \mathrm{pp}$.

Carle KJ, Hastings PA. 1982. Selection of meiofaunal prey by the darter goby, Gobionellus boleosoma (Gobiidae). Estuaries 5, 316-318.

Chao A. 2005. Species richness estimation. Pages 7909-7916 in N. Balakrishnan, C. B. Read, and B. Vidakovic, editors. Encyclopedia of statistical sciences. Wiley, New York, New York, USA.

Clement M, Snell Q, Walker P, Posada D, Crandall K. 2002. TCS: Estimating gene genealogies. Parallel and Distributed Processing Symposium, International Proceedings, $2,184 \mathrm{pp}$.

Coen, L.D., M.W. Luckenbach and D.L. Breitburg. 1999a. The role of oyster reefs as essential fish habitat: A review of current knowledge and some new perspectives. Amer. Fish. Soc. Symp. 22:438-454.

COI. 2014. The Genbank Submissions Handbook. NCBI. Bethesda, MD, p. 11 https://www.ncbi.nlm.nih.gov/books/NBK51157/pdf/Bookshelf_NBK51157.pdf

Conn CH. 1989. The reproductive biology and behavior of Gobiosoma $\bar{b}$ osci: the naked goby. (Unpublished Master's thesis). Lamar University.

Cote J, Clobert J, Brodin T, Fogarty S, Sih A. 2010. Personality-dependent dispersal: characterization, ontogeny and consequences for spatially structured populations. Philos. Trans. R. Soc. B Biol. Sci. 365: 4065-4076.

Crabtree RE and Middaugh DP. 1982. Oyster shell size and the selection of spawning sites by Chasmodes bosquianus, Hypleurochilus geminatus, Hypsoblennius ionthas (Pisces, Blennidae) and Gobiosoma bosci (Pisces, Gobbidae) in two South Carolina estuaries. Estuaries 5: 150-155.

D'Aguillo MC, Harold AS, Darden TL. 2014. Diet composition and feeding ecology of the naked goby Gobiosoma bosc (Gobiidae) from four western Atlantic estuaries. Journal of Fish Biology. 85: 355-373.

Dahlberg, MD and Conyers JC. 1972. An ecological study of Gobiosoma bosci and G. ginsburgi (Pices, Gobiidae) on the Georgia coast. Fishery Bulletin 71: 279-287.

Dawson CE. 1966. Studies on the gobies (Pisces: Gobiidae) of Mississippi Sound and adjacent waters. The American Midland Naturalist 76: 379-409.

Excoffier L, Laval G, Schneider S. 2005. Arlequin (Version 3.0): An integrated software package for population genetics data analysis. Evolutionary Bioinformatics 1: 47-50.

Fratini S, Vannini, M. 2002. Genetic differentiation in the mud crab Scylla serrata(Decapoda: Portunidae) within the Indian Ocean. Journal of Experimental Marine Biology and Ecology. 272, pp.103-116. 
680

681

682

683

684

685

686

687

688

689

690

691

692

693

694

695

696

697

698

699

700

701

702

703

704

705

706

707

708

709

710

711

712

713

714

715

716

717

718

719

720

721

722

723

724
Gain IE, Brewton RA, Robillard MM, Johnson KD, Smee DI, Stunz GW. 2017. Macrofauna using intertidal oyster reef varies in relation to position within the estuarine habitat mosaic. Marine Biology 164: 8.

Gotelli NJ, Colwell RK. (2001). Quantifying biodiversity: procedures and pitfalls in the measurement and comparison of species richness. Ecology Letters 4: 379-391.

Gula J, Molemaker MJ, McWilliams JC. 2015. Gulf stream dynamics along the Southeastern US Seaboard. Journal of Physical Oceanography 45: 690-715.

Harding JM. 1999. Selective feeding behavior of larval naked gobies Gobiosoma bosc and blennies Chasmodes bosquianus and Hypsoblennius hentzi: preference for bivalve veligers. Marine Ecology Progress Series 179: 145-153.

Harding JM, Mann R. 2000. Estimates of naked goby (Gobiosoma bosc), striped blenny (Chasmodes bosquianus) and eastern oyster (Crassostrea virginica) larval production around a restored Chesapeake Bay oyster reef. Bulletin of Marine Science 66(1): 29-45.

Harley CD, Hughes RA, Hultgren KM, Miner BG, Sorte CJ, Thornber CS, Rodriguez LF, Tomanek L, Williams SL. 2006. The impacts of climate change in coastal marine systems. Ecology letters, 9: 228-241.

Hellberg ME. 2009. Gene flow and isolation among populations of marine animals. Annual Review of Ecology and Systematics 40: 291-310.

Hendon JR, Peterson MS, Comyns BH. 2000. Spatial-temporal distribution of larval Gobiosoma bosc in water adjacent to natural and altered marsh-edge habitats of Mississippi coastal waters. Bulletin of Marine Science 66: 143-156.

Hildebrand SF, Cable LE. 1938. Further notes on the development and life history of some teleosts at Beaufort, N.C. U.S. Bureau of Fisheries Bulletin 48: 505-642.

Huelsenbeck JP, Ronquist F. 2001. MRBAYES: Bayesian inference of phylogeny. Bioinformatics 17: 754-755

Jahn AE. 1976. On the midwater fish faunas of Gulf Stream rings with respect to habitat differences between slope water and northern Sargasso Sea. PhD Thesis, Woods Hole Oceanographic Institution, Woods Hole, MA.

Joy DA, Feng X, Mu J, Furuya T, Chotivanich K, Krettli AU, Ho M, Wang A, White NJ, Suh E, Beerli P. 2003. Early origin and recent expansion of Plasmodium falciparum. Science. 300: 318-321.

Kleckner RC, McCleave JD. 1982. Entry of migrating American eel leptocephali into the Gulf Stream system. Helgol€ander Meeresuntersuchungen 35: 329-339.

Kocher TD, Thomas WK, Meyer A, Edwards SV, Paabo S, Villablanca FX, Wilson AC. 1989. Dynamics of mitochondrial DNA evolution in animals: amplification and sequencing with conserved primers. Proc. Natl. Acad. Sci. USA 86: 6196-6200.

Kohn YY, Clements KD. 2011. Pelagic larval duration and population connectivity in New Zealand triplefin fishes (Tripterygiidae). Environmental Biology of Fishes 91: 275-286.

Lankford TE, Targett TE. 1994. Suitability of estuarine nursery zones for juvenile weakfish (Cynoscion regalis): effects of temperature and salinity on feeding, growth, and survival. Marine Biology 119: 611-620.

Lasso-Alcala OM, Lasso C, Smith ML. 2005. The first record of the naked goby Gobiosoma bosc (Pisces: Gobiidae) from the north coast of South America. Revista de Biología Tropical 53: 1-2. 
Lederhouse TM. 2009. Naked gobies (Gobiosoma bosc) as indicators of oyster reef restoration success. (Unpublished master's thesis). University of Maryland, College Park.

Lehnert RL, Allen DM. 2002. Nekton use of subtidal oyster shell habitat in a southeastern US estuary. Estuaries 25: 1015-2024.

Leis JM, McCormick MI. 2002. The biology, behavior, and ecology of the pelagic larval stage of coral reef fishes. In: Coral Reef Fishes: Dynamics and Diversity in a Complex Ecosystem. Sale PF, ed. USA: Academic Press. San Diego, CA. pp 171-199.

Luettich RA, Carr SD, Reynolds-Fleming JV, Fulcher CW, McNinch JE. Semi-diurnal seiching in a shallow, micro-tidal lagoonal estuary. Cont. Shelf Res., 22 (11-13) (2002), pp. 1669 1681.

Markle DF, Grant GC. 1970. The summer food habits of young-of-the-year striped bass in three Virginia rivers. Chesapeake Science 11: 50-54.

Massmann WH, Norcross JJ, Joseph EB. 1963. Distribution of larvae of the naked goby, Gobiosoma bosci, in the York River. Chesapeake Science 4: 120-125.

Mila B, Girman DJ, Kimura M. and Smith, T.B., 2000. Genetic evidence for the effect of a postglacial population expansion on the phylogeography of a North America songbird. Proceedings of the Royal Society of London B: Biological Sciences, 267 (1447),pp.1033-1040.

Mila B, Van Tassell JL, Calderon JA, Ruber L, Zardoya R. 2017. Cryptic lineage divergence in marine environments: genetic differentiation at multiple spatial scales in the widespread intertidal goby Gobiosoma bosc. Ecology and Evolution 00: 1-10.

Miller C, Guillory V. 1980. A comparison of marsh fish communities using the Wegener ring. Proceedings of the annual conference of southeast association fish and wildlife agencies 34: 223-233.

Moody KN, Hunter SN, Childress MJ, Blob RW, Schoenfuss HL, Blum MJ, Ptacek MB. 2015. Local adaptation despite high gene flow in the waterfall-climbing Hawaiin goby, Sicyopterus stimpsoni. Molecular Ecology 24: 545-563.

Mora C, Sale PF. 2002. Are populations of coral reef fish open or closed? Trends in Ecology and Evolution 17: 422-428.

Moritz, C., \& Cicero, C. (2004). DNA barcoding: promise and pitfalls. PLoS biology, 2(10), e354.

Nelson TC. 1928. On the association of the common goby (Gobiosoma bosci) with the oyster, including a case of parasitism. Natural History 28: 78-84.

Nero L. 1976. The natural history of the naked goby Gobiosoma bosc (Perciformes: Gobiidae). MS Thesis. Old Dominion University, Norfolk VA. 85 p.

Ohman MC, Munday PL, Jones GP, Caley MJ. 1998. Settlement strategies and distribution patterns of coral-reef fishes. Journal of Experimental Marine Biology and Ecology 225: 219-238.

Paerl HW, Crosswell JR, Van Dam B, Hall NS, Rossignol KL, Osburn CL, Hounshell AG, Sloup RS, Harding LW Jr. 2018. Two decades of tropical cyclone impacts on North Carolina's estuarine carbon, nutrient and phytoplankton dynamics: implications for biogeochemical cycling and water quality in a stormier world. Biogeochemistry: 1-26.

Palumbi SR. 1994. Genetic divergence, reproductive isolation, and marine speciation. Annual Review of Ecology and Systematics 25: 547-572.

Palumbi SR, Warner RR. 2003. Why gobies are like hobbits. Science 299: 51-52. 
Pappalardo P, Pringle J, Wares J, Byers J. 2015. The location, strength, and mechanisms behind marine biogeographic boundaries of the east coast of North America. Ecography 38: 722 731.

Peterson MS, Ross ST. 1991. Dynamics of littoral fishes and decapods along a coastal estuarine gradient. Estuarine and coastal shelf sciences 33: 467-483.

Pietrafesa LJ, Janowitz GS, Wittman PA. 1985. Physical oceanographic processes in the Carolina Capes. Oceanography of the Southeastern US Continental Shelf (ed. by L.P. Atkinson, D.W. Menzel and K.A. Bush), pp. 23-32. Coastal and Estuarine Sciences, Vol. 2. American Geophysical Union, Washington, DC.

Pringle JM, Wares JP. 2007. Going against the flow: maintenance of alongshore variation in allele frequency in a coastal ocean. Marine Ecology Progress Series 335: 69-84.

Pringle JM, Blakeslee AMH, Byers JE, Roman J. 2011. Asymmetric dispersal allows an upstream region to control population structure throughout a species' range. Proceedings of the National Academy of Science 108: 15288-15293.

Riginos C, Douglas KE, Jin Y, Shanahan DF, Treml EA. 2011. Effects of geography and life history traits on genetic differentiation in benthic marine fishes. Ecography 34: 566-575.

Robertson D. 2001. Population maintenance among tropical fishes: inference from small island endemics. Proceedings of the National Academy of Sciences USA 98: 5667-5670.

Roche DG, Torchin ME. 2007. Established population of the North American Harris mud crab Rhithropanopeus harrisii in the Panama Canal. Aquat. Invasions 2: 155-161.

Ross SW, Rohde FC. 2004. The Gobioid fishes of North Carolina (Pisces, Gobioidei). Bulletin of Marine Science 74: 287-323.

Schludermann E, Tritthart M, Humphries P, Keckeis, H. 2012. Dispersal and retention of larval fish in a potential nursery habitat of a large temperate river: an experimental study. Can. J. Fish. Aquat. Sci. 69: 1302-1315.

Shanks AL. 2009. Pelagic larval duration and dispersal distance revisited. Biological Bulletin 216: 373-385.

Shenker JM, Hepner DJ, Frere PE, Currence LE, Wakefield WW. 1983. Upriver migration and abundance of naked goby (Gobiosoma bosci) larvae in the Patuxent River estuary, Maryland. Estuaries 6: 36-42.

Shima JS, Swearer SE. 2009. Larval quality is shaped by matrix effects: implications for connectivity in a marine metapopulation. Ecology 90: 1255-1267.

Shulman M, Bermingham E. 1995. Early life histories, ocean currents, and the population genetics of Caribbean reef fishes. Evolution 49: 897-910.

Skilleter GA, Loneragan NR. (2003). Assessing the importance of coastal habitats for fisheries, biodiversity and marine reserves: A new approach taking into account "habitat mosaics." Aquatic Protected Areas What works best and how do we know? World Congress on Aquatic Protected Areas, 14-17 August. Cairns, Australia, pp 240-249.

Sotka EE, Wares JP, Barth JA, Grosberg RK, Palumbi SR. 2004. Strong genetic clines and geographical variation in gene flow in the rocky intertidal barnacle Balanus glandula. Molecular Ecology 13: 2143-2156.

Stewart CB, Scharf FS. 2008. Estuarine recruitment, growth, and first-year survival of juvenile red drum in North Carolina. Transactions of the American Fisheries Society 137: 1089 1103. 
856

857

858

859

860

861

862

863

864

865

866

867

868

869

870

871

872

873

874

875

876

877

878

879

880

881

882

883

884

Thacker, C. 2011. Systematics of Gobiidae. In The Biology of Gobies (Patzner, R. A., Van Tassell, J. L., Kovacic, M. \& Kapoor, B. G., eds), pp. 129-136. Enfield, NH: Science Publishers.

Thacker C. 2011. Systematics of Gobiidae. In: The Biology of Gobies (Patzner, R. A., Van Tassell, J. L., Kovacic, M. \& Kapoor, B. G., eds), pp. 129-136. Enfield, NH: Science Publishers.

Thiel R, Scholle J, Schulze S. 2012. Forst record of the naked goby Gobiosoma bosc (Lacépède, 1800) in European waters. Bioinvasions Records 1: 295-298.

Tolley KA, Groeneveld JC, Gopal K, Matthee CA. 2005. Mitochondrial DNA panmixia in spiny lobster Palinurus gilchristi suggests a population expansion. Marine Ecology Progress Series, 297, pp.225-231.

Van Tassell JL. 2011. Gobiiformes of the Americas. In: The Biology of Gobies (Patzner, R. A., Van Tassell, J. L., Kovacic, M. \& Kapoor, B. G., eds), pp. 139-176. Enfield, NH: Science Publishers.

Van Tassell JL, Joyeux J-C, Macieira RM, Tornabene L. 2015. Status of Gobiosoma (Teleostei: Gobiidae) from Brazil: description of a new species, redescription of G. hemigymnum, molecular phylogeny of the genus, and key to Atlantic species. Zootaxa 4: 451-480.

Walther BA, Morand S.(1998). Comparative performance of species richness estimation methods. Parasitology 116: 395-405.

Waples RS. 1998. Separating the wheat from the chaff: patterns of genetic differentiation in high gene flow species. Journal of Heredity 89: 438-450.

Ward RD, Zemlak TS, Innes BH, Last PR, Hebert PD. 2005. DNA barcoding Australia's fish species. Philosophical Transactions of the Royal Society of London, Series B, Biological Sciences 1462: 1847-1857.

Whipple AC, Luettich RA, Seim HE. 2006. Measurements of Reynold's stress in a wind-driven lagoonal estuary. Ocean Dynamics 56: 169-185.

Witman JD, RJ Etter, Smith F. 2004. The relationship between regional and local species diversity in marine benthic communities: a global perspective. Proceedings of the National Academy of Science 101:15664-15669. 


\section{Table $\mathbf{1}$ (on next page)}

Site information and sample data

List of site names and abbreviations, locations, average salinities, salinity classification, number of haplotypes per population, population-level genetic diversity, and the proportion of singleton haplotypes (out of all detected haplotypes) per population. Population-level genetic diversity was not calculated for HPC. 


\begin{tabular}{|c|c|c|c|c|c|c|c|c|c|c|c|}
\hline $\begin{array}{l}\text { Site } \\
\text { Abbrev }\end{array}$ & Site Name & Location & $\begin{array}{l}\text { Mean } \\
\text { Salinity } \\
\text { (ppt) }\end{array}$ & $\begin{array}{c}\text { Standard } \\
\text { Deviation } \\
\text { Salinity } \\
\end{array}$ & $\begin{array}{c}\text { Salinity } \\
\text { Classification }\end{array}$ & $\begin{array}{c}\text { Number } \\
\text { of } \\
\text { Samples }\end{array}$ & $\begin{array}{c}\text { Total } \\
\text { Number of } \\
\text { Haplotypes }\end{array}$ & $\begin{array}{l}\text { Expected \# } \\
\text { haplotypes }\end{array}$ & $\begin{array}{c}\text { \# samples } \\
\text { to reach } \\
\text { asymptote }\end{array}$ & $\begin{array}{l}\text { Genetic } \\
\text { Diversity }\end{array}$ & $\begin{array}{c}\text { Proportion } \\
\text { of Singleton } \\
\text { Haplotypes } \\
\end{array}$ \\
\hline GSC & $\begin{array}{l}\text { Goose Creek, } \\
\text { Washington, NC }\end{array}$ & Pamlico & 3.08 & 1.97 & low & 34 & 8 & $\begin{array}{l}22.53 \\
( \pm 2.36)\end{array}$ & 550 & 0.46 & 0.50 \\
\hline MLC & $\begin{array}{l}\text { Mallard Creek, } \\
\text { Washington, NC } \\
\text { North Creek }\end{array}$ & Pamlico & 3.62 & 1.76 & low & 19 & 5 & $9.65( \pm 1.33)$ & 65 & 0.39 & 0.40 \\
\hline NCL & $\begin{array}{l}\text { Landing, Belhaven, } \\
\text { NC }\end{array}$ & Pamlico & 8.21 & 1.45 & medium & 21 & 6 & $\begin{array}{l}13.40 \\
( \pm 1.23)\end{array}$ & 80 & 0.43 & 0.50 \\
\hline WRC & $\begin{array}{l}\text { Wright's Creek, } \\
\text { Belhaven, NC }\end{array}$ & Pamlico & 9.55 & 0.93 & medium & 14 & 2 & $2.44( \pm 0.14)$ & 15 & 0.14 & 0.00 \\
\hline FSL & $\begin{array}{l}\text { Fisher's Landing, } \\
\text { New Bern, NC }\end{array}$ & Neuse & 2.91 & 1.78 & low & 7 & 2 & $2.57( \pm 0.14)$ & 8 & 0.29 & 0.50 \\
\hline CQC & $\begin{array}{l}\text { Cahooque Creek, } \\
\text { Havelock, NC } \\
\text { Matthew's Point }\end{array}$ & Neuse & 3.64 & 3.03 & low & 15 & 8 & $\begin{array}{l}29.94 \\
( \pm 2.91)\end{array}$ & 365 & 0.76 & 0.75 \\
\hline MTP & NC & Neuse & 10.33 & 4.15 & medium & 16 & 5 & $9.62( \pm 1.27)$ & 55 & 0.45 & 0.60 \\
\hline POC & $\begin{array}{l}\text { Pin Oak Court, } \\
\text { Merrimon, NC }\end{array}$ & Neuse & 9.65 & 4.17 & medium & 4 & 3 & $\begin{array}{c}4.36( \pm 0.21) \\
13.61\end{array}$ & 12 & 0.83 & 0.33 \\
\hline CDI & Cedar Island, NC & Neuse & 14.21 & 4.09 & medium & 17 & 6 & $( \pm 1.70)$ & 70 & 0.51 & 0.50 \\
\hline $\mathrm{HPC}_{2}$ & $\begin{array}{l}\text { Hoop Pole Creek, } \\
\text { Atlantic Beach, NC }\end{array}$ & $\begin{array}{l}\text { Bogue } \\
\text { Sound }\end{array}$ & 30 & $\mathrm{n} / \mathrm{a}$ & high & 8 & 3 & $3.57( \pm 0.12)$ & 30 & $\mathrm{n} / \mathrm{a}$ & 0.33 \\
\hline
\end{tabular}




\section{Figure 1}

Sample locations and their associated haplotype frequencies

Within the eastern part of North Carolina (USA), Gobiosoma bosc were collected from 5 sites on the Pamlico River (3-10 ppt), and 5 sites along the Neuse river (3-15 ppt), as well as a single site from Bogue Sound (30 ppt), which feeds into the Pamlico Sound. Haplotype frequencies are shown for sites along the Pamlico (GSC = Goose Creek; MLC = Mallard Creek; $\mathrm{NCL}=$ North Creek Landing; $\mathrm{WRC}=$ Wright's Creek), the Neuse (FSL = Fisher's Landing; CQC $=$ Cahooque Creek; MTP = Matthew's Point; POC = Pin Oak Court; CDI = Cedar Island), and Bogue Sound (HPC = Hoop Pole Creek). Colored pie pieces represent shared haplotypes within North Carolina, and black pie pieces represent the collective proportion of singleton haplotypes per population (see Table 1 and Table S1 for more information). Base map layers courtesy of d-maps.com
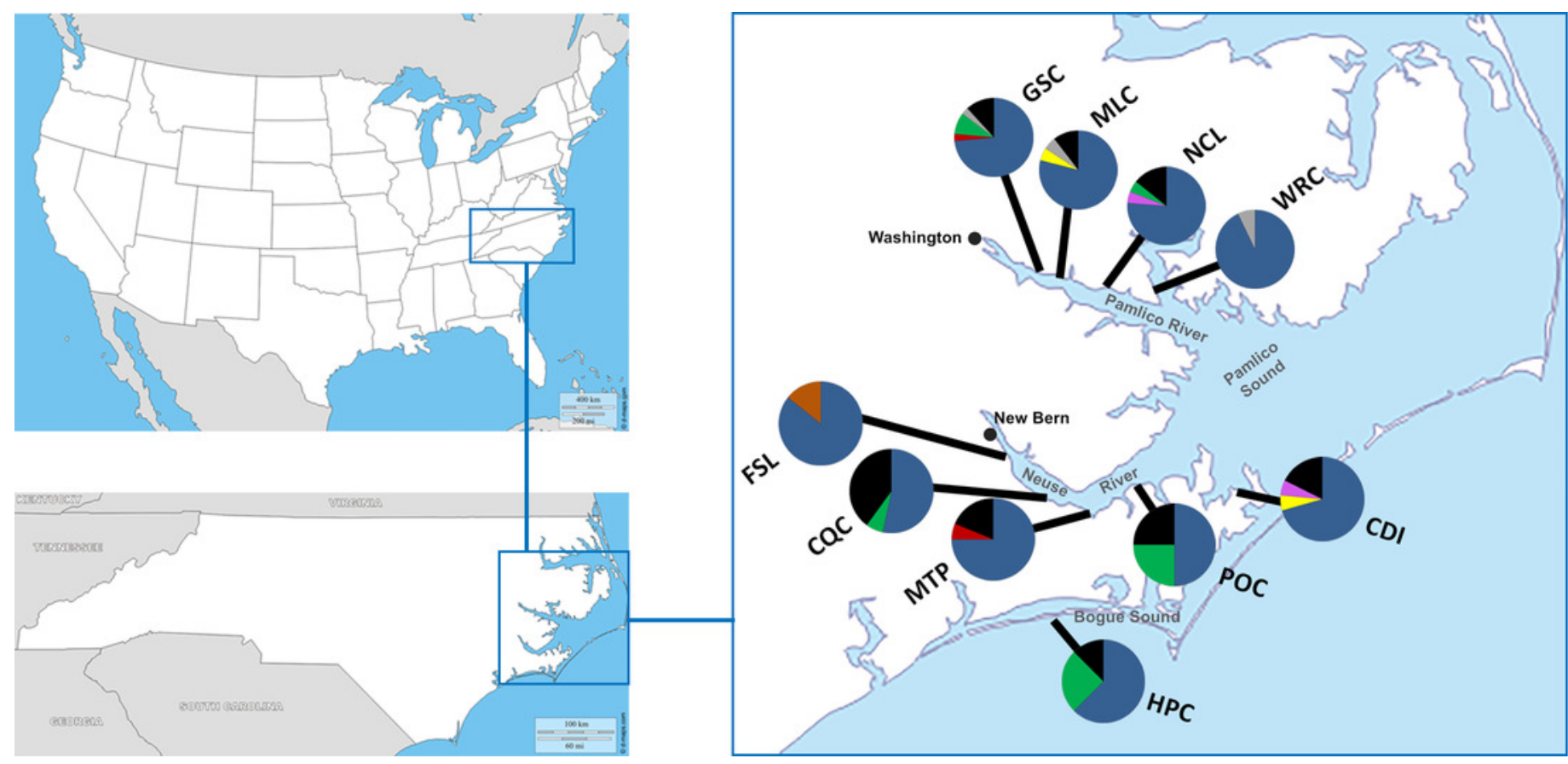
Figure 2

Haplotype network - North Carolina

Subregions include: NC-P (Pamlico), NC_N (Neuse), NC_B (Bogue Sound). The size of the circle is representative of the number of occurrences for each haplotype (see key in upper left).
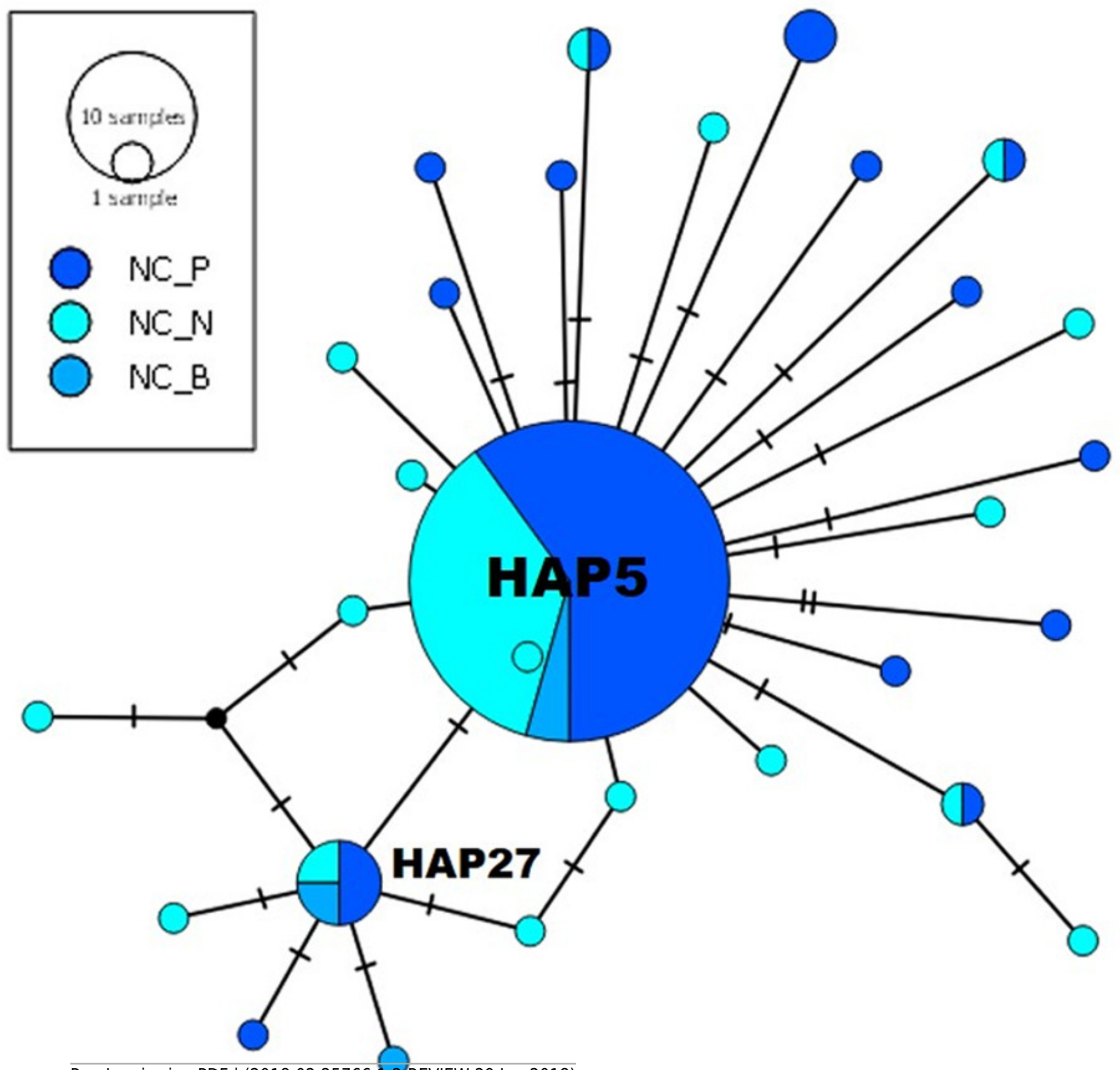
Figure 3

MDS plot of North Carolina populations

Pairwise FST data were analyzed using a resemblance matrix and plotted using nMDS. Points closer together are more similar in their haplotype frequencies than those more distant. Fish sampled from sites along the Pamlico River appear as triangles (GSC, MLC, NCL, WRC), and fish sampled from the Neuse appear as circles (FSL, CQC, MTP, POC). Fish from Bogue Sound appear as a square (HPC).

Non-metric MDS

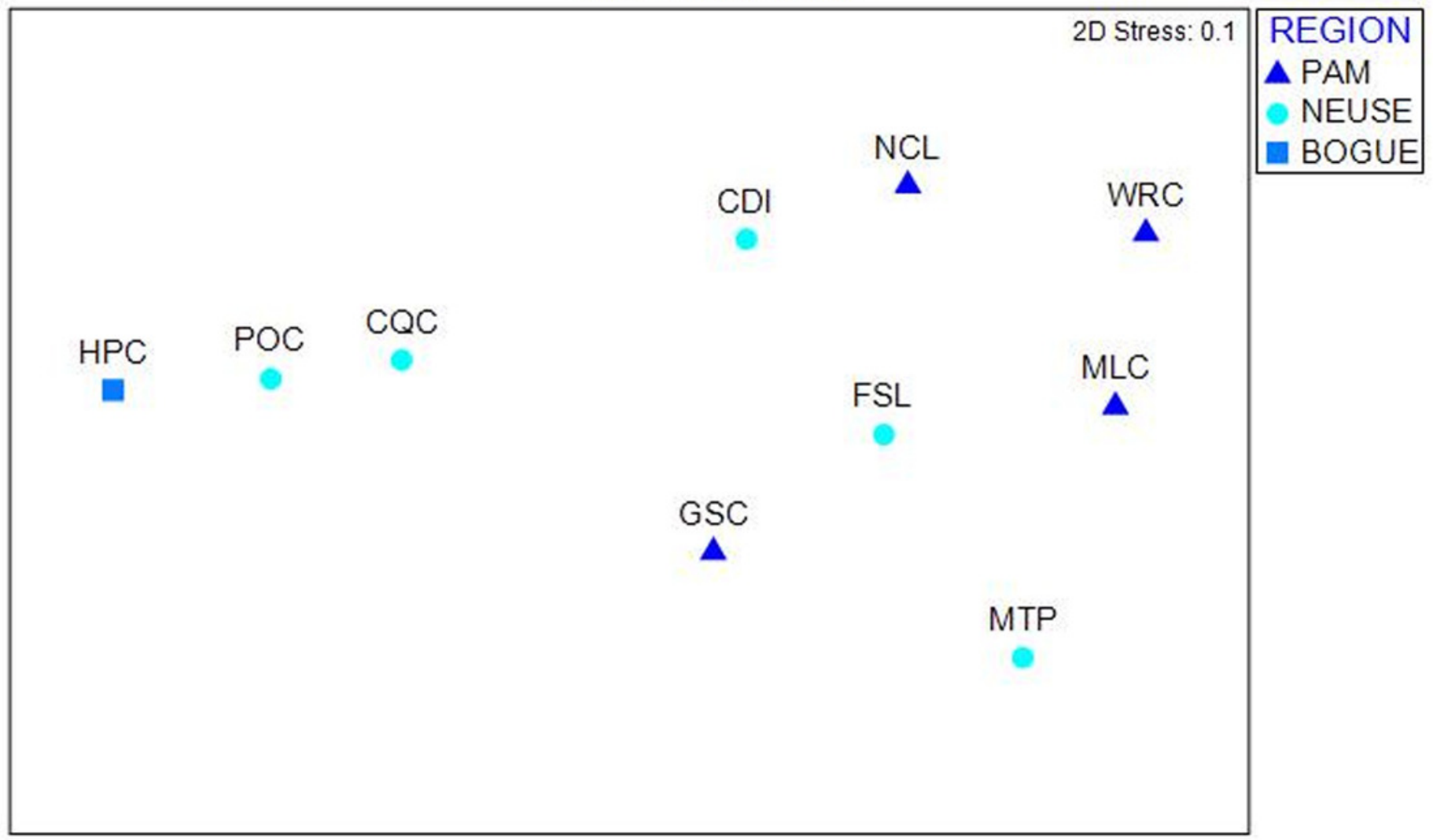




\section{Figure 4}

Rarefaction and extrapolation curves

The upper graph represents accumulation (SOBS) and estimator curves of haplotypes in the two North Carolina estuaries, scaled by the number of individuals. The lower graph extrapolates an asymptote based on the number of unique haplotypes sampled from fish within each estuary. 

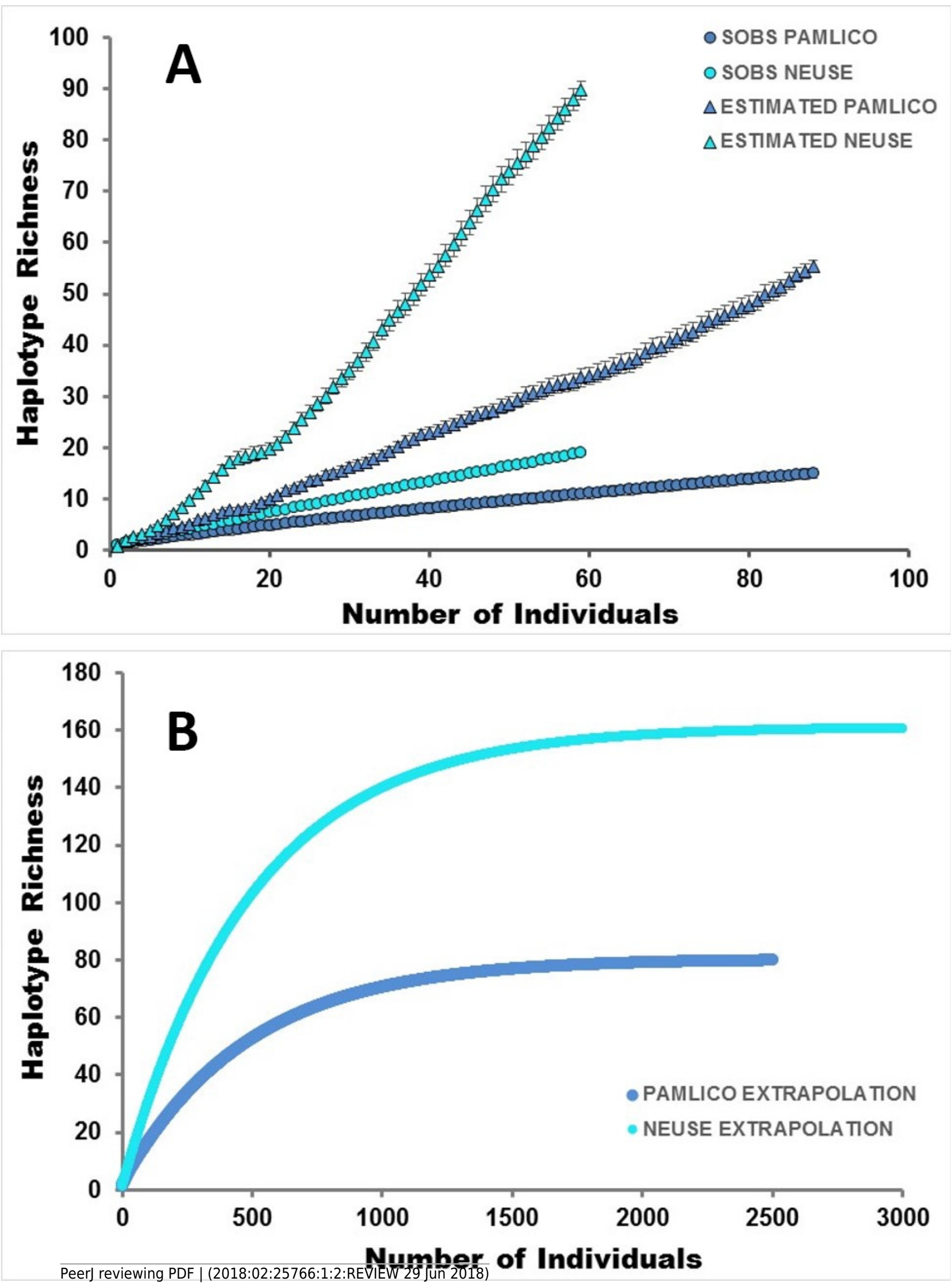
Figure 5

Salinity and genetic diversity

Dark blue diamonds = Pamlico; light blue circles $=$ Neuse. Salinity was averaged across 4 time intervals and regressed with (A) genetic diversity and $(B)$ proportion of singleton haplotypes. Salinity standard deviations are also plotted for genetic diversity (C) and proportion of singleton haplotypes (D).
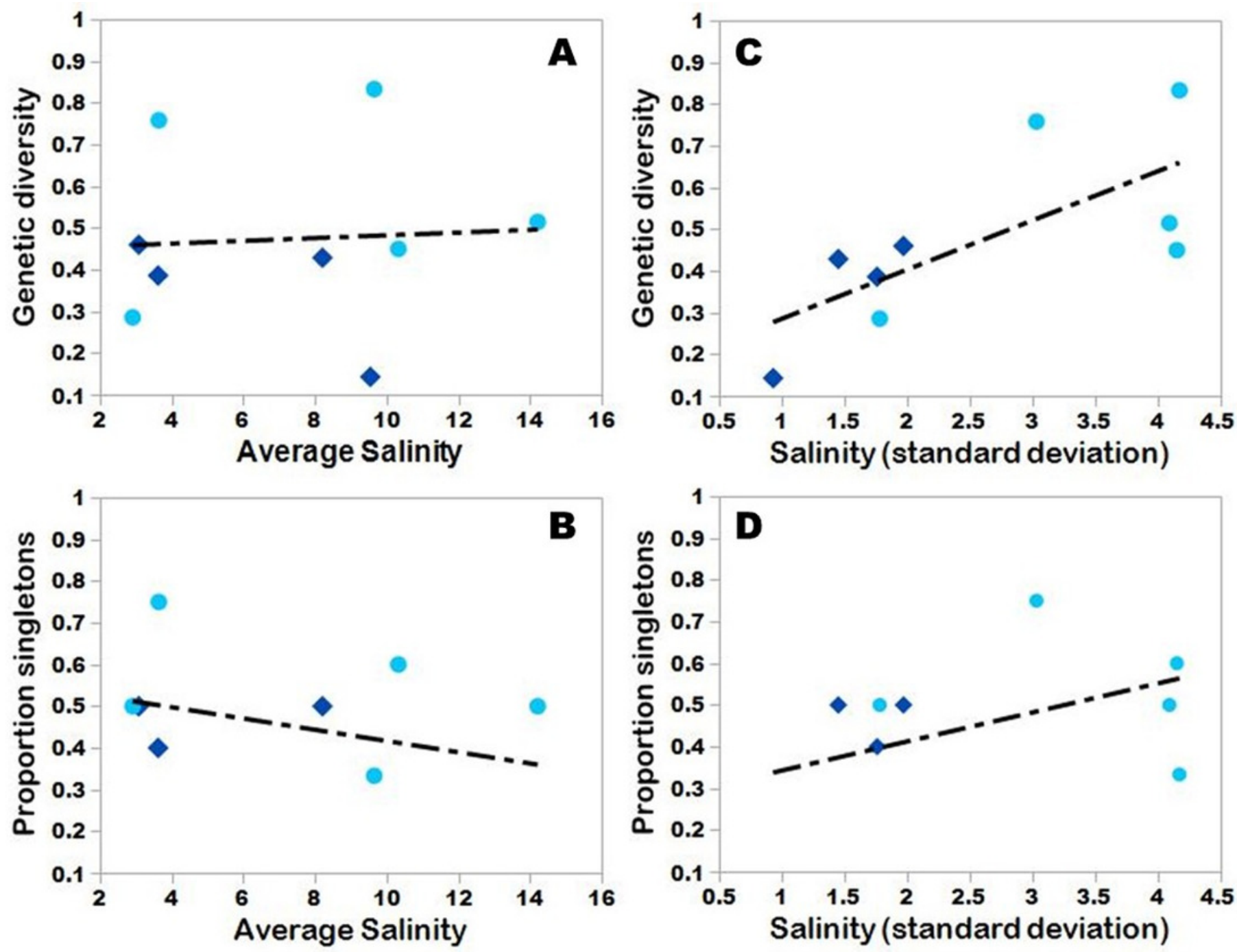


\section{Figure 6}

Haplotype network of Atlantic and Gulf of Mexico populations

Subregions included the following: MIDATL (Mid Atlantic, including New York and Virginia), NC_P (NC Pamlico), NC_N (NC Neuse), NC_B (NC Bogue), SC (South Carolina), FLA (Atlantic Florida, including Jacksonville (JAFL) and Indian River (IRFL), FLG (Gulf Florida, including Cedar Key (CKFL) and Tampa Bay (TBFL)), FLP (Florida panhandle, including Apalachicola (APFL) and Destin (DEFL)), GOM (Gulf of Mexico, including Empire, Louisiana (EMLA), Ocean Springs, Mississippi (OSMS), and Galveston, Texas (GATX)), and GERM (Weser Estuary, Germany). This figure represents an incidence-based TCS network analysis of all haplotypes and their connections throughout the sampled region in the Atlantic and Gulf of Mexico. Much of the data comes from Mila et al. (2017) (acquired from Genbank) and also our recent data from North Carolina estuaries.

\section{ATLANTIC POPULATIONS}

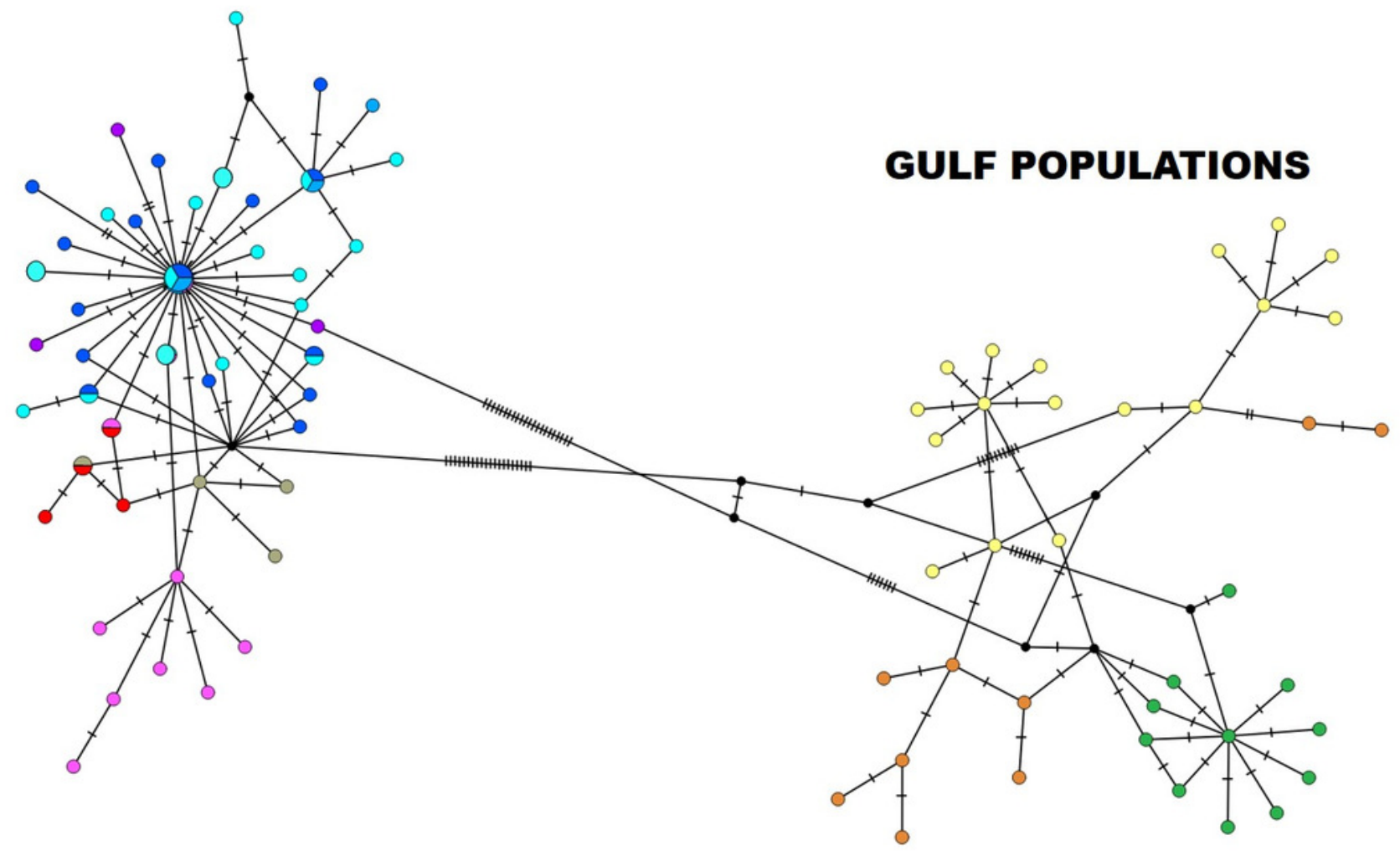

